\title{
PENGEMBANGAN BUKU PENGAYAAN PENGETAHUAN "PANDANGAN FISIKA TERHADAP PERISTIWA MENCAIRNYA ES DI KUTUB"
}

\author{
Syifa Fauziah*), Desnita, Cecep E. Rustana \\ Prodi Fisika FMIPA UNJ, Jl. Pemuda No 10, Jakarta 13220 \\ ${ }^{*}$ syifasyifasp@gmail.com
}

\begin{abstract}
Abstrak
Penelitian ini bertujuan untuk mengembangkan buku pengayaan pengetahuan materi mencairnya es di kutub berdasarkan kompetensi 3.9 kelas XI, yaitu menganalisis gejala pemanasan global, efek rumah kaca, dan perubahan iklim serta dampaknya bagi kehidupan dan lingkungan. Dalam melakukan penelitian digunakan metode Research and Development yang mengacu pada pendapat Dick \& Carey. Telah dilakukan survey untuk mengetahui kebutuhan buku pengayaan terhadap 4 sekolah, toko buku, serta Pusat Kurikulum dan Perbukuan. Dari hasil survey didapatkan ketersediaan buku pengayaan dengan kompetensi mencairnya es di kutub berkisar antara 7 hingga 8 judul. Guna menilai keseluruhan buku pengayaan, dilakukan uji keterbacaan kepada siswa SMA yang menghasilkan prosentase skor rerata sebesar $87 \%$ dengan rincian skor $88 \%$ pada komponen materi, $84 \%$ pada komponen penyajian, $88 \%$ pada komponen bahasa, dan $87 \%$ pada komponen grafika. Hasil tersebut menunjukkan bahwa materi pada buku pengayaan mampu meningkatkan motivasi siswa untuk mencari tahu lebih lanjut tentang peristiwa mencairnya es di kutub, ditambah lagi dengan penyajian kalimat dan ilustrasi yang memperjelas isi materi. Sehingga dapat disimpulkan bahwa buku pengayaan pengetahuan "Pandangan Fisika Terhadap Peristiwa Mencairnya Es Di Kutub" memperoleh predikat Sangat Baik.
\end{abstract}

Kata Kunci: buku pengayaan pengetahuan, efek rumah kaca, pemanasan global, mencairnya es di kutub Abstract

This research aim to develop knowledge enrichment book of ice melting in North Pole based on competence 3.9 grade XI, that is to analyze the indication of global warming, greenhouse effect, climate change, and the impact for life and environment. In this research, applied Research and Development Method refer to Dick \& Carey. Survey has done to know the necessity of enrichment book in four schools, book stores, and Pusat Kurikulum dan Perbukuan. The result is availability of enrichment book with North Pole ice melting competence around 7 until 8 book titles. To evaluate the whole enrichment book, validation test is done to high school's students and giving the results as mean score percentage as $85 \%$ with details like $86 \%$ for content, $81 \%$ for presentation, $87 \%$ for language, and $85 \%$ for graphic. The results show that the content of enrichment book are able to increase student's motivation to search deeper about North Pole's ice melting phenomenon, furthermore the presentation of sentences and illustrations that clarify the content. So it can be concluded that knowledge enrichment book "Physics Opinion To North Pole Ice Melting Phenomenon" obtain the Very Good predicate.

Keywords: knowledge enrichment book, greenhouse effect, global warming, North Pole's Ice Melting

\section{Pendahuluan}

Salah satu dampak dari pemanasan global adalah mencairnya lapisan es di kutub. National Center for Scientific Research (CNRS) yang berbasis di Paris, Perancis seperti dikutip Kantor Berita AFP (24/1/2008) melaporkan, sepanjang dua tahun terakhir, wilayah Arktik di Kutub Utara kehilangan lapisan es seluas dua kali wilayah
Perancis atau sepuluh kali luas Pulau Jawa. Kesimpulan itu didasarkan pada pengukuran luas lapisan es di Arktik. Pada tahun 1980, lapisan es Arktik masih 7,8 juta $\mathrm{km}^{2}$. CNRS meriset, pada September 2006 lapisan es itu menyusut menjadi 5,3 juta $\mathrm{km}^{2}$. Bahkan setahun berikutnya lapisan es yang tersisa hanya 4,13 juta $\mathrm{km}^{2}$. Artinya, hanya dalam setahun, lapisan es yang hilang mencapai 1,17 juta $\mathrm{km}^{2}$. Dalam 20 tahun terakhir, sudah $40 \%$ lapisan yang meleleh. Para ilmuwan memprediksi, 
lapisan es di Kutub Utara benar-benar hilang mulai musim panas tahun 2080. Namun, dengan simulasi iklim yang lebih canggih berbasis komputer, kondisi tersebut diperkirakan akan terjadi lebih cepat, yaitu antara tahun 2030-2050. Mencairnya lapisan es Arktik disebabkan oleh suhu bumi yang mulai meningkat akibat tingginya konsentrasi gas rumah kaca di atmosfer bumi seperti uap air $\left(\mathrm{H}_{2} \mathrm{O}\right)$, karbon dioksida $\left(\mathrm{CO}_{2}\right)$, ozon $\left(\mathrm{O}_{3}\right)$, dinitrogen oksida $\left(\mathrm{N}_{2} \mathrm{O}\right)$, metana $\left(\mathrm{CH}_{4}\right)$, sulfurheksafluorida $\left(\mathrm{SF}_{6}\right)$, perfluorokarbon (PFCs), hidrofluorokarbon (HFCs), CFC, $\mathrm{NO}$, dan $\mathrm{SO}_{2}$, yang dikeluarkan oleh kendaraan bermotor, pabrik industri, serta aktivitas manusia lainnya. Akibat kenaikan kadar gas rumah kaca, makin banyak sinar infra merah yang terperangkap oleh gas tersebut sehingga intensitas efek rumah kaca akan naik dan mengakibatkan suhu bumi meningkat [1].

Pemerintah Republik Indonesia telah menambahkan Pemanasan Global menjadi salah satu Kompetensi Dasar mata pelajaran Fisika kelas XI pada Kurikulum 2013, sebagai upaya meningkatkan pengetahuan masyarakat tentang dampak peristiwa pemanasan global dan kesadaran untuk melestarikan lingkungan. Tertulis pada KD 3.9 yaitu menganalisis gejala pemanasan global, efek rumah kaca, dan perubahan iklim serta dampaknya bagi kehidupan dan lingkungan. Selain menjadikannya materi pembelajaran di sekolah, hal lain yang juga dapat dilakukan adalah dengan pemberian informasi melalui buku pengayaan pengetahuan.

Menurut Peraturan Menteri Pendidikan Nasional Republik Indonesia Nomor 2 Tahun 2008 tentang Buku, buku pengayaan adalah buku yang memuat materi yang dapat memperkaya buku teks pendidikan dasar, menengah dan perguruan tinggi. Buku pengayaan dianjurkan penggunaannya untuk menambah pengetahuan dan wawasan peserta didik [2]. Buku pengayaan pengetahuan merupakan buku-buku yang dapat mengembangkan pengetahuan (knowledge development) peserta didik, bukan sebagai science (baik untuk ilmu pengetahuan alam maupun sosial) yang merupakan bidang kajian. Buku pengayaan pengetahuan berfungsi untuk memperkaya wawasan, pemahaman, dan penalaran peserta didik [3].

\section{Metode Penelitian}

Pengembangan buku pengayaan pengetahuan dilakukan di Laboratorium Pendidikan Fisika Fakultas MIPA Universitas Negeri Jakarta pada bulan Februari hingga Mei 2016. Metode penelitian yang digunakan mengacu pada penelitian pengembangan Dick dan Carey dengan tahapannya yaitu

1. Mengidentifikasi kebutuhan instruksional dan menulis tujuan instruksional umum;

2. Melakukan analisis instruksional;

3. Mengidentifikasi perilaku dan karakteristik awal peserta didik;

4. Menulis tujuan instruksional khusus;

5. Menyusun alat penilaian hasil belajar;

6. Menyusun strategi instruksional;

7. Mengembangkan bahan instruksional;

8. Menyusun desain dan melaksanakan evaluasi formatif; dan

9. Sistem instruksional [4].

Fokus penelitiannya adalah untuk menghasilkan buku pengayaan pengetahuan "Pandangan Fisika terhadap Peristiwa Mencairnya Es di Kutub" yang layak digunakan dan dapat meningkatkan pemahaman siswa. Dalam menilai kelayakan buku pengayaan pengetahuan digunakan instrumen yang mengacu pada indikator yang dikeluarkan oleh Pusat Kurikulum dan Perbukuan. Komponen penilaian dibagi menjadi empat yaitu (1) materi, dengan 5 sub indikator, (2) penyajian, dengan 4 sub indikator, (3) bahasa, dengan 2 sub indikator, dan (4) grafika, dengan 4 sub indikator. Instrumen validasi akan diberikan kepada ahli materi, ahli media, ahli pembelajaran, dan beberapa siswa untuk menilai keseluruhan buku pengayaan.

\section{Hasil dan Pembahasan}

Hasil survey peneliti terhadap buku pengayaan di perpustakaan beberapa sekolah, seperti SMA Negeri 12 Jakarta yang memiliki 9 judul buku pengayaan, juga SMA Negeri 103 Jakarta yang memiliki 8 judul buku. Sedangkan SMA Negeri 31 Jakarta dan MAN 20 Jakarta tidak memiliki buku pengayaan pengetahuan bertemakan mencairnya es di kutub. Begitu juga dengan buku-buku pengayaan yang terdapat pada salah satu toko buku besar di Jakarta, hanya memiliki 8 judul dengan tema yang sama.

Hasil survey ke Pusat Kurikulum dan Perbukuan juga menghasilkan informasi indikator penilaian buku pengayaan pengetahuan seperti pada Tabel 1. 
Tabel 1. Indikator penilaian yang dikeluarkan oleh Puskurbuk

\begin{tabular}{|c|c|}
\hline NO. & KOMPONEN DAN BUTIR \\
\hline A. & MATERI \\
\hline 1. & $\begin{array}{l}\text { Materi mendukung pencapaian tujuan } \\
\text { pendidikan nasional. }\end{array}$ \\
\hline 2. & $\begin{array}{l}\text { Materi tidak bertentangan dengan } \\
\text { peraturan dan perundang-undangan } \\
\text { yang berlaku di Indonesia. }\end{array}$ \\
\hline 3. & $\begin{array}{l}\text { Materi merupakan karya orisinal } \\
\text { (bukan hasil plagiat), tidak } \\
\text { menimbulkan masalah SARA dan tidak } \\
\text { diskriminasi gender. }\end{array}$ \\
\hline 4. & $\begin{array}{l}\text { Materi memiliki kebenaran keilmuan, } \\
\text { sesuai dengan perkembangan ilmu yang } \\
\text { mutakhir, sahih, dan akurat. }\end{array}$ \\
\hline 5. & $\begin{array}{l}\text { Materi memaksimalkan penggunaan } \\
\text { sumber-sumber yang sesuai dengan } \\
\text { kondisi Indonesia dan erat dengan } \\
\text { konteks ke-Indonesia-an. }\end{array}$ \\
\hline B. & PENYAJIAN \\
\hline 1. & $\begin{array}{l}\text { Penyajian materi runtut, bersistem, } \\
\text { lugas, dan mudah dipahami. }\end{array}$ \\
\hline 2. & $\begin{array}{l}\text { Penyajian materi mengembangkan } \\
\text { sikap spiritual dan sosial. }\end{array}$ \\
\hline 3. & $\begin{array}{l}\text { Penyajian materi mengembangkan } \\
\text { pengetahuan dan menumbuhkan } \\
\text { motivasi untuk berpikir lebih jauh. }\end{array}$ \\
\hline 4. & $\begin{array}{l}\text { Penyajian materi mengembangkan } \\
\text { keterampilan, dan memotivasi untuk } \\
\text { berkreasi dan berinovasi. }\end{array}$ \\
\hline C. & BAHASA \\
\hline 1. & $\begin{array}{l}\text { Bahasa yang digunakan etis, estetis, } \\
\text { komunikatif, dan fungsional, sesuai } \\
\text { dengan pembaca sasaran. }\end{array}$ \\
\hline 2. & $\begin{array}{l}\text { Bahasa (ejaan, tanda baca, kosakata, } \\
\text { kalimat, dan paragraf) sesuai dengan } \\
\text { kaidah dan istilah yang digunakan } \\
\text { baku. }\end{array}$ \\
\hline D. & GRAFIKA \\
\hline 1. & $\begin{array}{l}\text { Kulit buku: ilustrasi mewakili isi, jenis } \\
\text { huruf memiliki keterbacaan tinggi, } \\
\text { menarik, komposisi seimbang dan } \\
\text { harmonis antara kulit depan, punggung } \\
\text { dan belakang }\end{array}$ \\
\hline 2. & $\begin{array}{l}\text { Tata letak konsisten dan sesuai antara } \\
\text { kulit buku (cover) dengan isi buku. }\end{array}$ \\
\hline
\end{tabular}

\begin{tabular}{|c|l|}
\hline NO. & \multicolumn{1}{|c|}{ KOMPONEN DAN BUTIR } \\
\hline 3. & $\begin{array}{l}\text { Jenis dan ukuran huruf, dan penomoran } \\
\text { pada seluruh isi buku konsisten }\end{array}$ \\
\hline 4. & $\begin{array}{l}\text { Ilustrasi sesuai dengan pembaca sasaran } \\
\text { dan memperjelas isi }\end{array}$ \\
\hline
\end{tabular}

dengan ketentuan kelayakan sebagai berikut.

1. Butir pada komponen materi harus berskor $\geq$ 6

2. Butir pada komponen penyajian, bahasa, dan grafika harus berskor $\geq 3$

3. Total skor akhir dari seluruh komponen setelah dikalikan dengan bobot komponen minimal 55 .

Perhitungan skor akhir dilakukan dengan persamaan:

$$
A \times 0,4+B \times 0,3+C \times 0,2+D \times 0,1
$$
berikut.

Adapun penentuan kelayakan buku sebagai

Tabel 2. Interpretasi kelayakan buku

\begin{tabular}{|c|c|}
\hline $\begin{array}{c}\text { TOTAL SKOR } \\
\text { AKHIR }\end{array}$ & MAKNA \\
\hline Skor $\geq 85$ & $\begin{array}{c}\text { Layak dengan predikat } \\
\text { Sangat Baik }\end{array}$ \\
\hline $55 \leq$ skor $<85$ & $\begin{array}{c}\text { Layak dengan predikat } \\
\text { Baik }\end{array}$ \\
\hline Skor $<55$ & Tidak Layak (TL) \\
\hline
\end{tabular}

Buku pengayaan pengetahuan dikembangkan dengan menambahkan gambar, data, dan informasi pendukung yang berhubungan dengan peristiwa mencairnya lapisan es di kutub, seperti pada Gambar 1. 


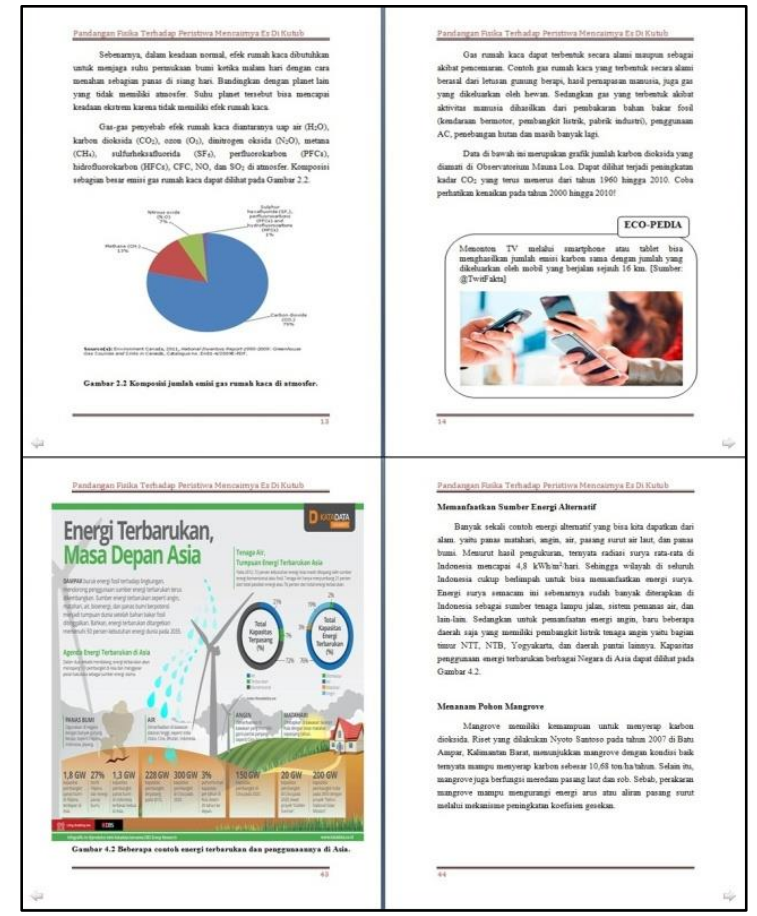

Gambar 1. Contoh isi buku pengayaan pengetahuan

Dari hasil uji keterbacaan buku pengayaan terhadap siswa SMA diperoleh prosentase skor rerata keseluruhan buku sebesar $87 \%$ atau Sangat Baik dengan rincian pada Tabel 3.

Tabel 3. Prosentase skor pada tiap komponen penilaian oleh siswa

\begin{tabular}{|c|c|c|}
\hline NO & KOMPONEN & $\begin{array}{c}\text { SKOR } \\
(\%)\end{array}$ \\
\hline 1. & Materi & 88 \\
\hline 2. & Penyajian & 84 \\
\hline 3. & Bahasa & 88 \\
\hline 4. & Grafika & 87 \\
\hline
\end{tabular}

Sedangkan untuk kelayakan buku yang divalidasi oleh ahli materi, ahli media, dan ahli pembelajaran diperoleh skor akhir sebesar 86 dengan rincian skor tiap komponen dapat dilihat pada Tabel 4.

Tabel 4. Rincian skor pada tiap komponen penilaian oleh ahli

\begin{tabular}{|c|c|c|}
\hline NO & KOMPONEN & SKOR \\
\hline 1. & Materi & 87 \\
\hline 2. & Penyajian & 83 \\
\hline 3. & Bahasa & 87 \\
\hline 4. & Grafika & 85 \\
\hline
\end{tabular}

Dari hasil tersebut, buku pengayaan pengetahuan "Pandangan Fisika Terhadap
Peristiwa Mencairnya Es Di Kutub" dinyatakan layak dengan predikat Sangat Baik. Buku pengayaan telah mampu meningkatkan motivasi siswa untuk mencari tahu lebih lanjut tentang peristiwa mencairnya es di kutub, ditambah lagi dengan penyajian kalimat dan ilustrasi yang memperjelas isi materi. Namun berdasarkan saran para ahli, buku pengayaan masih membutuhkan perbaikan dengan penambahan indikator pencapaian pada tiap bab, konsep fisis berkaitan dengan peristiwa mencairnya es di kutub, dan evaluasi sederhana seperti teka-teki silang, atau kegiatan menjodohkan.

\section{Simpulan}

Buku pengayaan pengetahuan "Pandangan Fisika terhadap Peristiwa Mencairnya Es Di Kutub" dinyatakan layak dengan predikat Sangat Baik.

Diharapkan kedepannya dilakukan pengembangan buku pengayaan pandangan fisika pada dampak pemanasan global selain mencairnya es di kutub.

\section{Ucapan Terima Kasih}

Peneliti mengucapkan terima kasih kepada Bapak Dr. Esmar Budi, M.T selaku Ketua Prodi Pendidikan Fisika, Ibu Dr. Desnita, M.Si dan Bapak Drs. Cecep E. Rustana Ph.D selaku Dosen Pembimbing, ahli materi, ahli media, ahli pembelajaran dan siswa SMA yang telah membantu dalam penelitian ini.

\section{Daftar Acuan}

[1] Diposaptono, S., Budiman, \& Agung, F. Menyiasati Perubahan Iklim: Di Wilayah Pesisir dan Pulau-pulau Kecil. Bogor (2009), hal. 7.

[2] Republik Indonesia. 2008. Permendiknas Republik Indonesia No.2 Tahun 2008 tentang Buku Bab I Pasal 1 Ayat 5. Jakarta.

[3] Pusat Kurikulum dan Perbukuan. 2015. Panduan Rapat Kerja Pelatihan dan Penilaian Buku Nonteks Pelajaran. Bogor: Kementerian Pendidikan dan Kebudayaan.

[4] Suparma, A. (2014). Desain Instruksional Modern. Jakarta: Erlangga. 